\title{
Poszukiwanie i dokumentowanie złóż wód termalnych w Polsce w latach 2010-2020 w aspekcie rozpoznania warunków hydrogeologicznych głębokich systemów wodonośnych
}

\author{
Jakub Sokolowski ${ }^{1}$
}

\begin{abstract}
Searching for and documenting thermal water deposits in Poland in 2010-2020 in terms of identifying hydrogeological conditions of deep aquifers. Prz. Geol., 69: 594-603; doi: 10.7306/2021.33

A b s tract. Recognition of the hydrogeological conditions of deep aquifers is possible mainly due to research carried out in deep boreholes. Such boreholes have been drilled in Poland since the 1950s. These are mainly exploration wells for hydrocarbon deposits, including research wells. Due to the purpose of these drillings, hydrodynamic and hydrochemical tests of aquifers with thermal waters are rare and carried out to a limited extent. Since 2010, there has been a clear increase in interest in the use of thermal waters in Poland. Due to the hydrogeological and geothermal conditions, the resources of these waters are made available in Poland through deep boreholes. The number of new geothermal wells has doubled in the last decade. Hydrodynamic tests (pumping, and hydrodynamic tests) and hydrochemical tests (analyses of physical and chemical properties of water, tests of the isotopic composition of water) carried out in these boreholes enable detailed characterization of the hydrogeological conditions prevailing in deep aquifers. They allow for the characterization of the pressure conditions in aquifers, the determination of the direction and velocity of groundwater flow, the duration of water in the rock massif, determination of the origin of water and presumed supply areas, as well as the hydrogeochemical characteristics of the waters. Therefore, the use of geothermal resources significantly contributes to the identification of the hydrogeological conditions of deep aquifers.
\end{abstract}

Keywords: thermal water, deep aquifers, geothermal well

Wodami termalnymi, zgodnie $\mathrm{z}$ art. 5 ustawy Prawo geologiczne i górnicze (Dz.U. 2021 poz. 1420, ze zm.), są określane wody podziemne mające na wypływie $\mathrm{z}$ ujęcia temperaturę nie mniejszą niż $20^{\circ} \mathrm{C}$, przy czym nie zalicza się do nich wód pochodzących $\mathrm{z}$ odwadniania wyrobisk górniczych. Ponieważ temperatura wód termalnych na powierzchni terenu zależy od wydajności, z jaką jest aktualnie eksploatowane dane ujęcie, umowną wartość $20^{\circ} \mathrm{C}$ odnosi się do wydajności ujęcia równej ustalonym i zatwierdzonym zasobom eksploatacyjnym. Zasoby eksploatacyjne definiuje się z kolei jako ilość wód podziemnych możliwą do pobrania z ujęcia w danych warunkach hydrogeologicznych i techniczno-ekonomicznych, z uwzględnieniem zapotrzebowania na wodę i przy zachowaniu wymogów ochrony środowiska (Rozporządzenie; Dz.U. 2016 poz. 2033). Bilansowaniem zasobów wód termalnych zajmuje się Państwowy Instytut Geologiczny - Państwowy Instytut Badawczy (PIG-PIB), który w ramach zadań państwowej służby geologicznej sporządza corocznie Bilans zasobów złóż kopalin w Polsce. Opracowanie to zawiera informacje o liczbie złóż wód termalnych, wielkości udokumentowanych zasobów tych złóż (zasobów eksploatacyjnych ujęć i zasobów dyspozycyjnych obszarów bilansowych) oraz stanie zagospodarowania i wielkości wydobycia, przedstawione $\mathrm{w}$ podziale regionalnym i administracyjnym. Bilansowanie zasobów wód termalnych polega zatem na zestawieniu ich ilości, bez uwzględnienia zasobów zgromadzonej w nich energii, której są nośnikiem.

Na koniec 2020 r. liczba złóż wód termalnych w Polsce wynosiła 36, a łączne zasoby eksploatacyjne wszystkich ujęć tego rodzaju wód wynosiły 5371,3 m³/h (Sokołowski, Skrzypczyk, 2021). W porównaniu do lat ubiegłych, obserwuje się wyraźny wzrost zarówno liczby złóż (ryc. 1), jak i wielkości zasobów (ryc. 2) - przykładowo w 2015 r. liczba złóż wód termalnych wynosiła 28 (zasoby eksplo- atacyjne $3930,3 \mathrm{~m}^{3} / \mathrm{h}$ ), a w $2010 \mathrm{r}$. jedynie 18 (zasoby eksploatacyjne $2276,7 \mathrm{~m}^{3} / \mathrm{h}$ ). Wyraźny wzrost liczby złóż wód termalnych i ich zasobów jest przede wszystkim wynikiem podjętych przed laty wielu działań administracyjnych, wśród których należy wymienić m.in. utworzenie przez Narodowy Fundusz Ochrony Środowiska i Gospodarki Wodnej systemu finansowania przedsięwzięć geotermalnych, wprowadzenie ,zerowej” stawki opłaty eksploatacyjnej za wydobywanie wód termalnych, czy zniesienie koncesji na poszukiwanie tych wód. Nie bez znaczenia są też rozwój technologiczny, który dokonał się w branży wiertniczej i energetyce w ostatnich latach, oraz doświadczenia z zakresu hydrogeologii zebrane od końca lat 90. XX w., kiedy to powstały pierwsze w Polsce ciepłownie geotermalne. Wszystko to umożliwia sięganie po niedostępne dotychczas zasoby. Nowe inwestycje geotermalne w znaczący sposób przyczyniły się do poprawy stanu rozpoznania głębokich systemów wodonośnych, co tym samym wpłynęło korzystnie na obniżenie ryzyka geologicznego realizacji kolejnych przedsięwzięć w przyszłości.

\section{CHARAKTERYSTYKA ZLÓŻ WÓD TERMALNYCH}

W artykule zaprezentowano wyniki prac geologicznych zakończonych udokumentowaniem zasobów eksploatacyjnych ujęć wód termalnych wykonanych w latach 2010-2020. W tym okresie odkryto siedemnaście złóż tych wód na Niżu Polskim i w Sudetach, a ich zasoby eksploatacyjne udokumentowano dwudziestoma głębokimi otworami geotermalnymi (tab. 1). Jest to znacząca liczba, bowiem przed 2010 r. w kraju odkryto zaledwie 18 złóż wód termalnych, z czego dziesięć było zlokalizowanych na Podhalu (ryc. 3). Poza niecką podhalańską złoża wód termalnych, zgodnie z klasyfikacją przyjętą w Bilansie Za-

\footnotetext{
${ }^{1}$ Państwowy Instytut Geologiczny - Państwowy Instytut Badawczy, ul. Rakowiecka 4, 00-975 Warszawa; jakub.sokolowski@pgi.gov.pl
} 


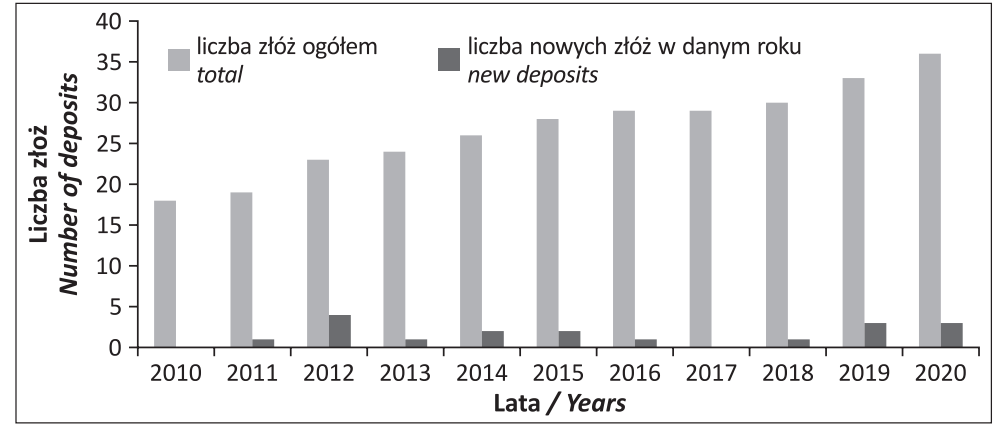

Ryc. 1. Liczba złóż wód termalnych w latach 2010-2020 (na podst. Bilansu Zasobów Złóż Kopalin w Polsce)

Fig. 1. Number of thermal water deposits in 2010-2020 (after Bilans Zasobów Złóż Kopalin w Polsce)

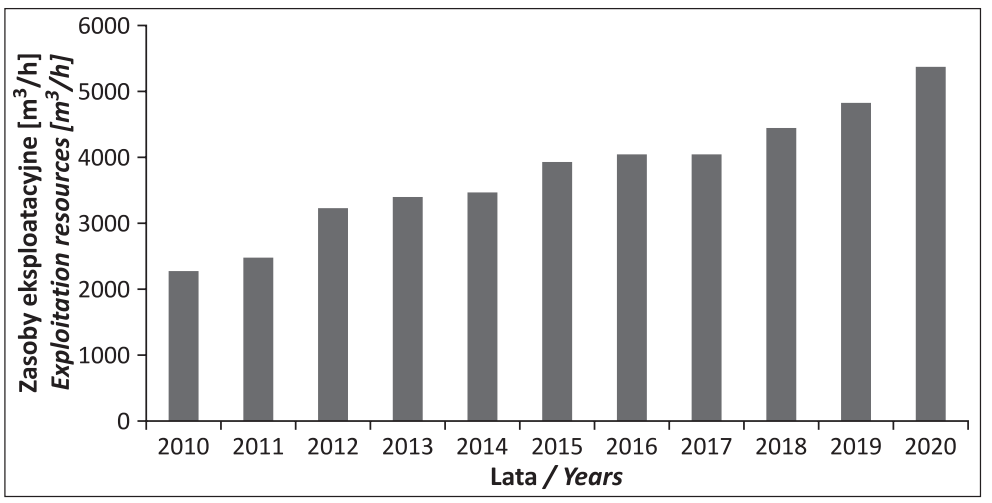

Ryc. 2. Zasoby eksploatacyjne ujęć wód termalnych w latach 2010-2020 (na podst. Bilansu Zasobów Złóż Kopalin w Polsce)

Fig. 2. Exploitation resources of geothermal wells in 2010-2020 (after Bilans Zasobów Złóż Kopalin w Polsce)

sobów Złóż Kopalin w Polsce (Sokołowski, Skrzypczyk, 2021), znajdowały się w: Łodzi, Uniejowie, Pyrzycach, Stargardzie, Mszczonowie, Skierniewicach, Poznaniu (otw. Swarzędz IGH-1) i Porębie Wielkiej.

W tabeli 2 przedstawiono krótką charakterystykę poszczególnych złóż wód termalnych wraz z przytoczeniem najistotniejszych wyników badań przeprowadzonych w poszczególnych otworach wiertniczych.

\section{Poddębice}

Poddębice znajdują się w centralnej części niecki mogileńsko-łódzkiej. Rejon ten był uznawany za obszar perspektywiczny występowania wód termalnych przydatnych do ogrzewania, co zostało potwierdzone wykonanym w 2010 r. otworem wiertniczym Poddębice GT-2 (Tadych i in., 2010). Wyniki wiercenia potwierdziły także obecność strefy bardzo głębokiego wysłodzenia wód, stwierdzonej wykonanymi pod koniec lat 60. XX w. otworami wiertniczymi Madaje Stare IG-1 i Sarnów IG-1. Otwór wiertniczy Poddębice GT-2 zakończono na głębokości 2101,0 m w marglach, wapieniach marglistych, mułowcach i iłowcach jury dolnej. Utworów jury środkowej i górnej na obszarze złoża nie stwierdzono. Bezpośrednio powyżej osadów jury dolnej zalegają drobno- i średnioziarniste piaskowce z iłowcami kredy dolnej (barrem - alb dolny), tworzące poziom wodonośny wód termalnych o miąższości 103,0 m. Strop warstwy wodonośnej nawiercono na głębokości 1962,0 m. W złożu panują warunki artezyjskie, a zwierciadło wody stabilizuje się $26 \mathrm{~m}$ ponad poziomem terenu. Wody termalne ujęto $\mathrm{w}$ interwale 1962,0-2059,0 m. Piaskowce charakteryzują się dobrymi właściwościami kolektorskimi. Ich porowatość wynosi 16-23\%, przepuszczalność $176,5 \mathrm{mD}$, a współczynnik filtracji $1,2 \cdot 10^{-6} \mathrm{~m} / \mathrm{s}$. Ujęte wody scharakteryzowano jako $\mathrm{HCO}_{3}-\mathrm{Na}-\mathrm{Ca}$ o mineralizacji ogólnej wynoszącej $0,3-0,5 \mathrm{~g} / \mathrm{dm}^{3}$. Temperatura wód na wypływie $\mathrm{z}$ ujęcia zmienia się w zakresie $60,5-72,2^{\circ} \mathrm{C}$. Woda nie zawiera trytu, a wyniki pozostałych oznaczeń składu izotopowego wody przedstawiają się następująco: $\delta^{18} \mathrm{O}=-10,66 \%$, $\delta^{2} \mathrm{H}=-77,0 \%$ i $\delta^{13} \mathrm{C}=$ $-12,4 \%$. Wyniki te zdają się wskazywać na zasilanie poziomu wodonośnego zachodzące pod koniec ostatniego zlodowacenia. Zasoby eksploatacyjne ujęcia ustalono w wysokości $252,0 \mathrm{~m}^{3} / \mathrm{h}$ przy depresji $85,3 \mathrm{~m}$. Wody termalne są wykorzystywane przede wszystkim w geotermii, także do celów rekreacyjnych $\mathrm{i}$ balneoterapeutycznych.

\section{Toruń}

W 2012 r. wody termalne udokumentowano po raz pierwszy w kujawskim odcinku antyklinorium środkowopolskiego (Biernat i in., 2011b). W Toruniu w 2009 r. wykonano dwa otwory wiertnicze: Toruń TG-1 (otwór produkcyjny) i Toruń TG-2 (otwór chłonny). Otworami tymi rozpoznano profil geologiczny do głębokości 2925,0 m, kończąc głębienie otworu TG-1 w mułowcach i iłowcach z wkładkami wapieni triasu dolnego (pstry piaskowiec górny). Trias środkowy (wapień muszlowy) jest reprezentowany przede wszystkim przez wapienie, których strop nawiercono na głębokości 2755,0 m. Trias górny jest wykształcony w postaci mułowców i iłowców kajpru oraz retyku. Strop tych utworów nawiercono na głębokości 2335,0 m. Ostatecznie, po likwidacji spodu otworu jego głębokość wynosi 2329,5 m. Głębokość drugiego z otworów TG-2 wynosi 2362,0 m. Powierzchnię spągową osadów triasu górnego stwierdzono tu na głębokości 2349,0 m. Wody termalne ujęto z utworów jury dolnej, tworzących poziom wodonośny o napiętym zwierciadle wody nawierconym na głębokości 1892,5-1903,0 m. Zwierciadło wody występuje pod dużym ciśnieniem i stabilizuje się na głębokości 17,5 m. Warstwę wodonośną, zbudowaną z drobno- i różnoziarnistych piaskowców przewarstwionych iłowcami i mułowcami (warstwy ksawerowskie i kłodawskie) zafiltrowano w interwałach 2133,0-2316,9 m (otw. TG-1) i 1937,5-2333,7 m (otw. TG-2). W profilu litologicznym jury dolnej utwory przepuszczalne stanowią od 40 do $80 \%$ ich ogólnej miąższości, a łączna miąższość poziomu wodonośnego wynosi od 442,5 do 446,0 m. Współczynnik porowatości piaskowców jury dolnej wynosi $26 \%$, ich średnia przepuszczalność to $1034 \mathrm{mD}$, a współczynnik filtracji mieści się w przedziale $6,8 \cdot 10^{-6}-1,7 \cdot 10^{-5} \mathrm{~m} / \mathrm{s}$. Wody termalne reprezentują typ Cl-Na, I, (F) o mineralizacji ogólnej wynoszącej 97,7$116,7 \mathrm{~g} / \mathrm{dm}^{3}$. Temperatura wody na wypływie $\mathrm{z}$ ujęć wynosi maksymalnie $60,5^{\circ} \mathrm{C}$. Woda pobrana $\mathrm{z}$ otworu TG-1 jest prawie pozbawiona trytu, którego stężenie wynosi $<2,0 \mathrm{TU}$. Zasoby eksploatacyjne ujęcia zatwierdzono w ilości 
Tab. 1. Zestawienie wyników najważniejszych badań wykonanych w otworach geotermalnych udokumentowanych w latach 2010-2020

Table 1. Summary of the results of the most important tests carried out in geothermal wells documented in 2010-2020

\begin{tabular}{|c|c|c|c|c|c|c|c|c|c|c|c|c|c|}
\hline \multirow[b]{2}{*}{ 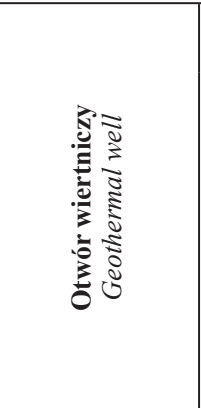 } & \multirow[b]{2}{*}{ 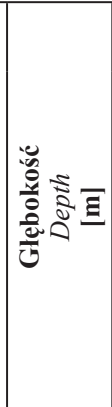 } & \multirow[b]{2}{*}{ 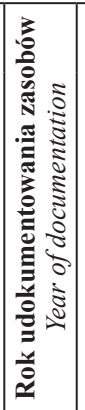 } & \multirow[b]{2}{*}{ 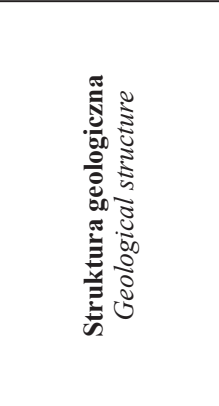 } & \multicolumn{10}{|c|}{$\begin{array}{c}\text { Poziom wodonośny } \\
\text { Aquifer } \\
\end{array}$} \\
\hline & & & & 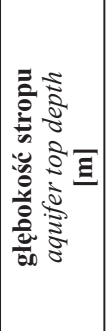 & 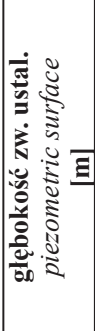 & $\frac{x}{0}$ & 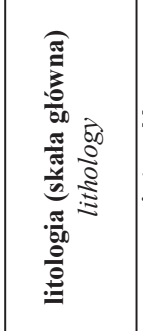 & 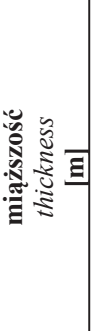 & 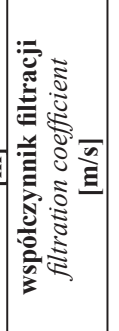 & 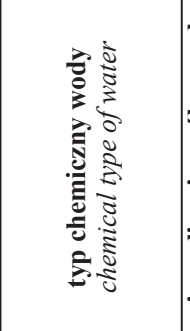 & 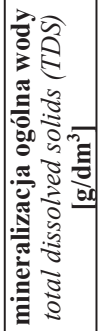 & 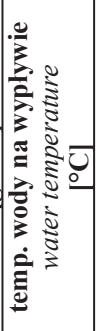 & 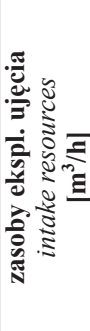 \\
\hline & 01,0 & 2011 & $\begin{array}{l}\text { niecka szcz. } \\
\text {-łódz.-miec }\end{array}$ & 62,0 & $+26,0$ & $\mathrm{~K}_{1}$ & jiask & 103,0 & $1,2 \cdot 10^{-6} \mid$ & $\mathrm{HCO}_{3}-\mathrm{Na}-\mathrm{Ca}$ & $0,3-0,5$ & \begin{tabular}{|c|}
$60,5-$ \\
72,2
\end{tabular} & 252,0 \\
\hline Toruń TG-1 & 95 & 2012 & antykl. środk. & 925 & 17,5 & $I$ & e & 442,5 & $1,7 \cdot 10^{-5}$ & $\mathrm{Cl}-\mathrm{Na}, \mathrm{I},(\mathrm{F})$ & 116,7 & 60,5 & 320,0 \\
\hline Toru & 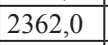 & 2012 & & & bd & & & 446,0 & $6,8 \cdot 10^{-6}$ & & 97,7 & b.d. & \\
\hline $\begin{array}{l}\text { Lidzt } \\
\text { Warn }\end{array}$ & 35,0 & 2012 & synekliza p & 77,0 & 22,7 & $\mathrm{~J}_{1}$ & piaskowce & 107,0 & $4,2 \cdot 10^{-5} \mid$ & Cl-Na, I & 1,3 & 21,0 & 120,0 \\
\hline Kleszczów GT-1 & 20,0 & 2012 & & 1484,0 & 49,2 & $\mathrm{~J}_{1-2}$ & askowce & 136,0 & \multirow{2}{*}{$\left|\begin{array}{c}2,3- \\
2,6 \cdot 10^{-5}\end{array}\right|$} & $1-\mathrm{Na}$ & 6,1 & 52,2 & 150,0 \\
\hline Kleszczów GT-2 & 1725,0 & 2012 & $\begin{array}{l}\text { nieck } \\
\text {-łódz }\end{array}$ & 1277,0 & 35,2 & $\mathrm{~T}_{3}-\mathrm{J}_{1-2}$ & piaskowce & 448,0 & & $\mathrm{Cl}-\mathrm{Na}$ & 1,4 & 52,2 & - \\
\hline $\begin{array}{l}\text { Tarnowo Podg. } \\
\text { GT-1 }\end{array}$ & 00 & 2012 & $\begin{array}{l}\text { niecka s } \\
\text {-łódz.-n }\end{array}$ & 1052,0 & 5,2 & $\mathrm{~J}_{1}$ & wce & 148,0 & $4,6 \cdot 10^{-5}$ & $\mathrm{Cl}-\mathrm{Na}, \mathrm{I}$ & 81,3 & 43,5 & 25,0 \\
\hline Trzęsacz GT-1 & 15,5 & 2013 & antykl. środk. & 14,5 & $+43,7$ & $J_{1}$ & Nce & 93,5 & $1,0 \cdot 10^{-4}$ & 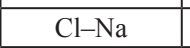 & 13,5 & 25,4 & 80,0 \\
\hline Karpniki KT-1 & 2010,0 & 2014 & Sudety & 793,5 & $+3,1$ & $\mathrm{C}_{2}$ & ity & 216,5 & $2,4 \cdot 10^{-5}$ & $\begin{array}{c}\mathrm{HCO}_{3}-\mathrm{S} \\
\mathrm{F},\end{array}$ & 0,5 & 56,0 & 44,0 \\
\hline & 1581,0 & 2014 & Sudety & 3,0 & 16,0 & $\mathrm{C}$ & y & 288,0 & $1,4 \cdot 10^{-6}$ & $\begin{array}{c}\mathrm{SO}_{4}-\mathrm{l} \\
\mathrm{Cl}- \\
\mathrm{F}, \mathrm{S}\end{array}$ & 0,5 & 37,3 & 20,5 \\
\hline yowice & 0,0 & 2015 & $\begin{array}{l}\text { niecka } \\
\text {-łódz.- }\end{array}$ & 7,0 & $+62,2$ & $\mathrm{~K}_{2}$ & piaskowce & 83,0 & $2,3 \cdot 10^{-4}$ & $\begin{array}{r}\mathrm{Cl}-\mathrm{SC} \\
\mathrm{I},\end{array}$ & 15,1 & 28,6 & 82,0 \\
\hline Celejów GT-2 & 1225,0 & 2015 & niecka $t$ & & 2 & & & 206,0 & $2,0 \cdot 10^{-6}$ & & $4 J, J$ & 29,2 & 28,0 \\
\hline Konin GT-1 & 2660,0 & 2016 & $\begin{array}{l}\mathrm{ni} \\
-\mathrm{-}\end{array}$ & 78,0 & 122,4 & $\mathrm{~J}_{1}$ & piaskowce & 63,0 & $5 \cdot 10^{-5}$ & $\mathrm{Cl}-\mathrm{Na}, \mathrm{I}$ & 150,4 & 92,0 & 114,0 \\
\hline GT-1 & 05,0 & 2018 & $\begin{array}{l}\text { niecka } \\
\text {-łódz. }\end{array}$ & 73,0 & 2,1 & $\mathrm{~J}_{1}$ & pias & 126,0 & $1,1 \cdot 10^{-5}$ & $\mathrm{Cl}-\mathrm{Na}$ & 2,6 & 51,8 & 49,0 \\
\hline Turek GT-1 & 51,0 & 2019 & \begin{tabular}{|l|} 
niecka \\
-łódz.-1 \\
\end{tabular} & 00,5 & 115,4 & $\mathrm{~J}_{1}$ & iaskowce & 48,3 & $2,7 \cdot 10^{-6}$ & $\mathrm{Cl}-\mathrm{Na}, \mathrm{I}, \mathrm{Fe}$ & 132,9 & 77,9 & 54,0 \\
\hline Socl & 40,0 & 2019 & niecka brzeżna & 1360,0 & $+22,3$ & $\mathrm{~K}_{1}$ & piaskowce & 132,6 & $5,1 \cdot 10^{-5}$ & \begin{tabular}{|c|}
$\mathrm{Cl}-\mathrm{HCO}_{3}-\mathrm{Ca}-$ \\
$\mathrm{Na}$ \\
\end{tabular} & 1,0 & 44,3 & 180,0 \\
\hline Wręcza GT-1 & 1668,0 & 2019 & $\mathrm{n}$ & 23,5 & d. & $\mathrm{K}_{1}$ & skowce & 119,6 & $6,7 \cdot 10^{-5}$ & & 0,4 & 40,1 & 150,0 \\
\hline Koło GT-1 & 2815,0 & 2019 & $\begin{array}{l}\text { niecka } \\
\text {-łódz.-1 }\end{array}$ & 2565,0 & 7 & 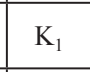 & e & 0 & $0^{-6}$ & e) & 9 & 1,3 & 0 \\
\hline Jachranka GT-1 & 30,5 & 2020 & niecka brzeżna & 24,0 & b.d. & $\mathrm{J}_{1}$ & piaskowce & 222,0 & $1,3 \cdot 10^{-5}$ & $\mathrm{Cl}-\mathrm{Na}, \mathrm{I}$ & 77,4 & 43,2 & 188,5 \\
\hline Jachranka GT-2K & $50,0^{1)}$ & 2020 & niecka brzeżna & $1883,0^{1)}$ & b.d. & $\mathrm{J}_{1}$ & piaskowce & $249,0^{1)}$ & $3,4 \cdot 10^{-5}$ & \begin{tabular}{|l|}
$\mathrm{Cl}-\mathrm{Na}, \mathrm{I},(\mathrm{Fe})$ \\
\end{tabular} & 67,6 & 42,5 & 201,0 \\
\hline $\begin{array}{l}\text { Tomaszów } \\
\text { Maz. GT-1 }\end{array}$ & 1577,0 & 20 & $\begin{array}{l}\text { niecka szcz.-mogil.- } \\
\text {-łódz.-miech. }\end{array}$ & 1437,0 & b.d. & $\mathrm{J}_{1}$ & ce & 128,0 & b.c & $\left(-1-11-C_{3}^{-1 N a}\right.$ & 0 , & 41, & 80,0 \\
\hline
\end{tabular}

${ }^{1)}$ podano po długości otworu kierunkowego

$320,0 \mathrm{~m}^{3} / \mathrm{h}$ przy depresji w otworze produkcyjnym $17,7 \mathrm{~m}$. Podstawą ustalenia zasobów w tej wysokości było potwierdzenie w praktyce możliwości chłonnych otworu TG-2 przy stałym ciśnieniu zatłaczania wynoszącym 6,0 bar. W 2020 r. otwór TG-1 poddano rekonstrukcji z uwagi na kolmatację filtra (Bystroń i in., 2020). Planuje się także wykonanie nowego otworu chłonnego z uwagi na utratę chłonności ujęcia TG-2. Po uruchomieniu dubletu geotermalnego wody mają być wykorzystywane do celów grzewczych.

\section{Lidzbark Warmiński}

Pierwsze, i jak dotąd jedyne, złoże wód termalnych na obszarze syneklizy perybałtyckiej (obniżenia nadbałtyckiego) udokumentowano w 2012 r. w Lidzbarku Warmińskim (Biernat i in., 2011d). Otwór wiertniczy Lidzbark
Warmiński GT-1 zakończono na głębokości 1035,0 m w mułowcach i iłowcach triasu górnego (retyku). Otworem ujęto poziom wodonośny jury dolnej przez zabudowanie filtra w głębokości 873,5-966,5 m. Warstwa wodonośna o miąższości $107,0 \mathrm{~m}$ jest zbudowana ze średnioi gruboziarnistych piaskowców kwarcowych, miejscami zlepieńców kwarcowych, przewarstwionych iłowcami i mułowcami (warstwy olsztyńskie). Zwierciadło wody nawiercono na głębokości $877,0 \mathrm{~m}$, a poziom statyczny ustabilizował się na głębokości $22,7 \mathrm{~m}$. Porowatość efektywna piaskowców wynosi ok. $30 \%$, a ich współczynnik filtracji $4,2 \cdot 10^{-5} \mathrm{~m} / \mathrm{s}$. Ujęte wody zalicza się do typu Cl-Na, I o mineralizacji ogólnej $21,3 \mathrm{~g} / \mathrm{dm}^{3}$. Maksymalna temperatura wody na wypływie z ujęcia wynosi $21,0^{\circ} \mathrm{C}$. Zasoby eksploatacyjne ujęcia zatwierdzono w ilości $120,0 \mathrm{~m}^{3} / \mathrm{h}$ przy depresji 7,7 m. Woda jest wykorzystywana do napełniania niecek basenów rekreacyjnych. 


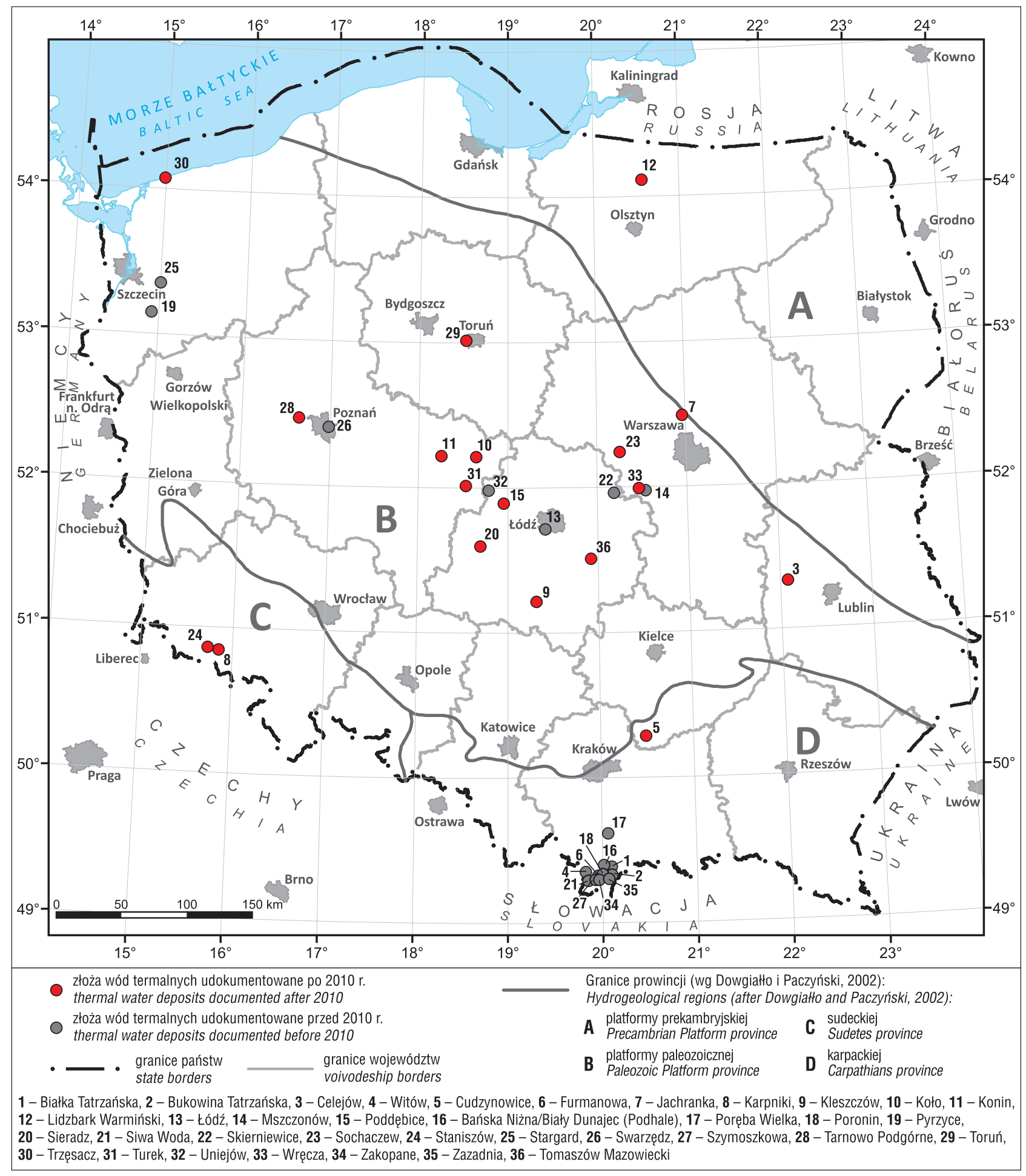

Ryc. 3. Lokalizacja złóż wód termalnych

Fig. 3. Location of thermal water deposits

\section{Kleszczów}

Złoże wód termalnych w Kleszczowie, położonym na granicy niecek łódzkiej i miechowskiej, rozpoznano dwoma otworami wiertniczymi: Kleszczów GT-1 (otwór produkcyjny) wykonanym w 2009 r. i Kleszczów GT-2 (otwór chłonny) ukończonym w 2011 r. (Biernat i in., 2011a). Pierwszym otworem GT-1 o głębokości 1725,0 m osiągnięto iłowce i piaskowce stropowej części triasu górnego, drugi zakończono w obrębie utworów jury dolnej. W otwo- rze GT-2 na głębokości 1620 m udokumentowano osady kredy górnej i dolnej, których obecności nie stwierdzono wcześniejszym wierceniem. Osady jury środkowej i dolnej wraz ze stropową partią utworów triasu górnego tworzą połączony poziom wodonośny o napiętym zwierciadle wody nawierconym na głębokości $1277,0 \mathrm{~m}$ w otworze GT-2 i 1484,0 m w otworze GT-1. Zwierciadło wody występuje pod dużym ciśnieniem i stabilizuje się na głębokości 35,2 m (otw. GT-2) i 49,2 m (otw. GT-1). Warstwa wodonośna jest zbudowana $\mathrm{z}$ drobno- i różnoziarnistych pia- 
Tab. 2. Zestawienie wyników składu izotopowego wód termalnych z otworów wiertniczych wykonanych w latach 2010-2020

Table 2. Summary of the results of the isotope composition of thermal waters from boreholes drilled in 2010-2020

\begin{tabular}{|l|c|c|c|}
\hline $\begin{array}{c}\text { Otwór wiertniczy } \\
\text { Geothermal well }\end{array}$ & $\begin{array}{c}\boldsymbol{\delta}^{\mathbf{1 8}} \mathbf{O} \\
{[\mathbf{\%}]}\end{array}$ & $\begin{array}{c}\mathbf{\delta}^{\mathbf{2}} \mathbf{H} \\
{[\mathbf{\%}]}\end{array}$ & $\begin{array}{c}\text { Tryt } \\
\text { Tritium } \\
{[\mathbf{T U}]}\end{array}$ \\
\hline Poddębice GT-2 & $-10,66$ & $-77,0$ & 0,0 \\
\hline Toruń TG-1 & - & - & $<2,0$ \\
\hline Kleszczów GT-1 & $-10,70^{1)}$ & $-75,7^{1)}$ & $0,0^{1)}$ \\
$-10,73^{2)}$ & $-75,4^{2)}$ & $2,2^{2)}$ \\
\hline Karpniki KT-1 & $-10,53$ & $-75,7$ & 0,0 \\
\hline Staniszów ST-1 & $-10,43$ & $-74,1$ & 0,0 \\
\hline Konin GT-1 & $-3,75$ & $-38,2$ & 0,3 \\
\hline Sieradz GT-1 & $-10,47$ & $-75,3$ & 0,0 \\
\hline Turek GT-1 & $-2,53$ & $-33,8$ & 0,1 \\
\hline Sochaczew GT-1 & $-10,46$ & $-76,9$ & 0,0 \\
\hline Wręcza GT-1 & $-10,25$ & $-74,6$ & 0,6 \\
\hline Koło GT-1 & $-6,31$ & $-48,2$ & 0,2 \\
\hline Jachranka GT-1 & $-5,07$ & $-42,6$ & 0,0 \\
\hline Jachranka GT-2K & $-5,22$ & $-43,0$ & 0,3 \\
\hline Tomaszów Maz. & $-11,02$ & $-78,3$ & 0,0 \\
\hline GT-1 & & \multicolumn{2}{|c}{} \\
\hline
\end{tabular}

1) 2009 r., ${ }^{2)} 2016 \mathrm{r}$.

skowców kwarcowych przewarstwionych iłowcami i mułowcami, często zapiaszczonymi. Miąższość poziomu wodonośnego wynosi od 136,0 m w otworze GT-1 do 448,0 m w otworze GT-2, a udział warstw przepuszczalnych w ogólnej miąższości poziomu wynosi ok. 80\%. Współczynnik filtracji utworów wodonośnych kształtuje się w granicach $2,3-2,6 \cdot 10^{-5} \mathrm{~m} / \mathrm{s}$. Otworem produkcyjnym do eksploatacji udostępniono interwał 1489,0-1620,0 m (bezfiltrowo), natomiast otwór chłonny został zafiltrowany w interwale 1282,3-1696,2 m. Wody termalne reprezentują typ $\mathrm{Cl}-\mathrm{Na}$ i charakteryzują się mineralizacją ogólną od $1,4 \mathrm{~g} / \mathrm{dm}^{3}$ w otworze GT-2 do $6,1 \mathrm{~g} / \mathrm{dm}^{3}$ w otworze GT-1. Maksymalna temperatura zmierzona na wypływie z ujęć wynosi $52,2^{\circ} \mathrm{C}$. Skład izotopowy wody pobranej z otworu GT-1 przedstawia się następująco: $\delta^{18} \mathrm{O}=-10,70 \%, \delta^{2} \mathrm{H}=$ $-75,7 \%$, $\delta^{13} \mathrm{C}=-13,7 \%$, tryt $=0,0$ TU (2009 r.) i $\delta^{18} \mathrm{O}=$ $-10,73 \%$ o, $\delta^{2} \mathrm{H}=-75,4 \%$, tryt $=2,2$ TU (2016 r.). Przypuszczalnie wody te infiltrowały do górotworu u schyłku ostatniego zlodowacenia. Zasoby eksploatacyjne ujęcia ustalono w wysokości $150,0 \mathrm{~m}^{3} / \mathrm{h}$ przy depresji w otworze produkcyjnym $55,0 \mathrm{~m}$. Podstawą ustalenia zasobów w tej wysokości było potwierdzenie w praktyce możliwości chłonnych otworu GT-2 przy stałym ciśnieniu zatłaczania wynoszącym 4,7 bar. Woda jest wykorzystywana do celów grzewczych.

\section{Tarnowo Podgórne}

W 2012 r. w Tarnowie Podgórnym, położonym w południowej części niecki szczecińskiej, rozpoznano i udokumentowano nowe złoże wód termalnych (Biernat i in., 2011c). Otwór wiertniczy Tarnowo Podgórne GT-1 zakończono na głębokości $1200,0 \mathrm{~m}$ po nawierceniu $30 \mathrm{~m}$ piaskowców, mułowców i iłowców triasu górnego (retyku). Otwór zafiltrowano w poziomie wodonośnym jury dolnej na głębokości 1080,0-1123,0 m, 1135,6-1147,9 m i 1154,1-1166,5 m. Warstwę wodonośną o miąższości $148,0 \mathrm{~m}$ i naporowym zwierciadle wody nawierconym na głębokości 1052,0 m tworzą głównie drobnoziarniste piaskowce kwarcowe, słabo i średnio zwięzłe, o spoiwie ilastym lub ilasto-krzemionkowym, przewarstwione iłowcami i mułowcami, niekiedy piaszczystymi (warstwy radowskie i mechowskie). Zwierciadło statyczne ustabilizowało się na głębokości 65,2 m. Szacuje się, że utwory przepuszczalne stanowią od 40 do $80 \%$ ogólnej miąższości warstwy wodonośnej. Porowatość efektywna piaskowców dochodzi do $36 \%$, a ich przepuszczalność osiąga maksymalnie $4593 \mathrm{mD}$. Współczynnik filtracji utworów wodonośnych wynosi $4,6 \cdot 10^{-5} \mathrm{~m} / \mathrm{s}$. Ujęte wody zaliczono do typu $\mathrm{Cl}-\mathrm{Na}$, I o mineralizacji ogólnej $81,3 \mathrm{~g} / \mathrm{dm}^{3}$. Maksymalna temperatura na wypływie z ujęcia wynosi $43,5^{\circ} \mathrm{C}$. Zasoby eksploatacyjne ujęcia zatwierdzono w ilości $225,0 \mathrm{~m}^{3} / \mathrm{h}$ przy depresji $26,9 \mathrm{~m}$. Woda ze złoża zaopatruje miejscowy kompleks basenów rekreacyjnych.

\section{Trzęsacz}

W 2013 r. udokumentowano pierwsze i jak dotąd jedyne złoże wód termalnych w pomorskim odcinku antyklinorium środkowopolskiego (Biernat i in., 2012). Otworem wiertniczym Trzęsacz GT-1 o głębokości ostatecznej $1215,5 \mathrm{~m}$ (pierwotnej 1224,5 m) ujęto wody termalne $\mathrm{z}$ utworów jury dolnej. Zalegają one na głębokości 527,51208,0 m i są wykształcone głównie jako naprzemianległe pakiety mułowców, iłowców i różnoziarnistych piaskowców. Zwierciadło wód podziemnych nawiercono na głębokości 1114,5 m. W złożu stwierdzono warunki artezyjskie - poziom statyczny ustabilizował się $43,7 \mathrm{~m}$ ponad powierzchnią terenu. Serię wodonośną tworzą utwory warstw mechowskich, głównie różnoziarniste piaskowce kwarcowe o spoiwie ilastym, na ogół średnio zwięzłe, zawierające miejscami rozproszony piryt i wtrącenia zwęglonej materii organicznej, przewarstwione iłowcami i mułowcami. W profilu litologicznym jury dolnej utwory przepuszczalne stanowią około $64 \%$ ich ogólnej miąższości, a ich udział w profilu warstw mechowskich jest mniejszy i wynosi ok. 54\%. Współczynnik filtracji utworów ujętych w interwałach 1011,0-1017,0 m, 1116,0-1135,0 m i 1154,0$1197,0 \mathrm{~m}$ wynosi $1,0 \cdot 10^{-4} \mathrm{~m} / \mathrm{s}$. Wodę z otworu scharakteryzowano jako $\mathrm{Cl}-\mathrm{Na}$ o mineralizacji ogólnej wynoszącej $13,5 \mathrm{~g} / \mathrm{dm}^{3}$ i maksymalnej temperaturze na wypływie z ujęcia $25,4^{\circ} \mathrm{C}$. Nie badano składu izotopowego wody, natomiast analizie poddano rozpuszczony w niej gaz, składający się w głównej mierze z azotu (86,4\% obj.). Zasoby eksploatacyjne ujęcia ustalono w wysokości $180,0 \mathrm{~m}^{3} / \mathrm{h}$ przy depresji 27,4 m. Złoże jest eksploatowane, a wydobywana woda jest wykorzystywana do hodowli ryb ciepłolubnych.

\section{Karpniki}

W Sudetach wody podziemne o temperaturze na wypływie z ujęcia powyżej $20^{\circ} \mathrm{C}$ są znane od dawna, jednak pod względem formalno-prawnym zalicza się je do wód leczniczych. W 2014 r. we wschodniej części karkonoskiego masywu granitoidowego, w strefie jego kontaktu z osłoną metamorficzną Rudaw Janowickich, wykonano otwór wiertniczy Karpniki KT-1 o głębokości 2010,0 m (Łukaczyński, Polaczek, 2014a). Udokumentowano nim pierwsze sudeckie złoże wód termalnych w rozumieniu przepisów ustawy Prawo geologiczne i górnicze. Wody termalne krążą tu w szczelinach masywu krystalicznego, zbudowanego z gruboziarnistych granitów (monzogranitów) porfi- 
rowatych, datowanych na karbon górny, którym towarzyszą różnego rodzaju utwory żyłowe (aplity, pegmatyty, mikrogranity z żyłami kwarcowymi i lamprofirami). W masywie granitoidowym występują zaburzenia tektoniczne, przeważnie dyslokacje o kierunkach NW-SE i NE-SW. Główny dopływ wód do otworu (ok. 80\% dopływu całkowitego) odbywa się ze strefy uskokowej nawierconej na głębokości 1793,5 m. Przepuszczalność występujących w tej strefie silnie pokruszonych granitów wynosi $34 \mathrm{mD}$. Ze skał bardziej zwięzłych, o przepuszczalności poniżej $1 \mathrm{mD}$, dopływ wód odbywa się mikroszczelinami. Zwierciadło swobodne stabilizuje się 3,1 m ponad powierzchnią terenu, a więc w złożu panują warunki artezyjskie. Współczynnik filtracji ujętych utworów wynosi $2,4 \cdot 10^{-5} \mathrm{~m} / \mathrm{s}$. Wody należą do typu $\mathrm{HCO}_{3}-\mathrm{SO}_{4}-\mathrm{Na}, \mathrm{F}, \mathrm{Rn}$ o mineralizacji ogólnej wynoszącej ok. $0,5 \mathrm{~g} / \mathrm{dm}^{3}$. Temperatura wód na wypływie z ujęcia wynosi $53,0-56,0^{\circ} \mathrm{C}$, zawartość fluorków 11,4 mg/dm ${ }^{3}$, a stężenie radonu 290,1 Bq/ $\mathrm{dm}^{3}$. Badania izotopowe wód wskazują na jej infiltracyjne pochodzenie $\left(\delta^{18} \mathrm{O}=-10,53 \%\right.$, $\delta^{2} \mathrm{H}=-75,7 \%$ o, $\delta^{13} \mathrm{C}=-8,3 \%$, tryt $=$ 0,0 TU). „Wiek” wody szacuje się prawdopodobnie na ponad 35 tysięcy lat. Zasoby eksploatacyjne ujęcia wynoszą $44,0 \mathrm{~m}^{3} / \mathrm{h}$ przy depresji 3,2 $\mathrm{m}$. Woda ze złoża jest wydobywana do ogrzewania kompleksu hotelowego.

\section{Staniszów}

W tym samym okresie co w Karpnikach prace wiertnicze zmierzające do udokumentowania zasobów wód termalnych prowadzono w odległym o ok. $10 \mathrm{~km}$ na zachód Staniszowie. Otwór wiertniczy Staniszów ST-1, zlokalizowany w centralnej części karkonoskiego masywu granitowego, osiągnął głębokość 1581,0 m (Łukaczyński, Polaczek, 2014b). Ogólna charakterystyka utworów systemu wodonośnego jest analogiczna do tej w Karpnikach, stąd pominięto ją w opisie złoża. Poziom wód o zwierciadłe napiętym nawiercono na głębokości 1293,0 m. Ustabilizowało się ono na głębokości 16,0 m. Główna strefa dopływu wód termalnych do otworu, z której następuje 43\% całkowitego przypływu, znajduje się w interwale 1364,4-1405,6 m. Średni współczynnik filtracji strefy zawodnionej wynosi $1,2-1,6 \cdot 10^{-6} \mathrm{~m} / \mathrm{s}$. Wody termalne ze złoża zaklasyfikowano do typu $\mathrm{SO}_{4}-\mathrm{HCO}_{3}-\mathrm{Cl}-\mathrm{Na}, \mathrm{F}, \mathrm{S}, \mathrm{Rn}$. Ich mineralizacja ogólna wynosi $0,5 \mathrm{~g} / \mathrm{dm}^{3}$, a maksymalna temperatura na wypływie z ujęcia osiąga $37,3^{\circ} \mathrm{C}$. Składniki swoiste są obecne w wodzie w ilości: fluorki - $12,7 \mathrm{mg} / \mathrm{dm}^{3}$, siarkowodór $2,5 \mathrm{mg} / \mathrm{dm}^{3}$, radon $-116 \mathrm{~Bq} / \mathrm{dm}^{3}$. Podobnie jak w Karpnikach, badania izotopowe wód wskazują na jej infiltracyjne pochodzenie $\left(\delta^{18} \mathrm{O}=-10,43 \%\right.$ o, $\delta^{2} \mathrm{H}=-74,1 \%$ o, $\delta^{13} \mathrm{C}=$ $-10,5 \%$, tryt $=0,0 \mathrm{TU})$. ,Wiek” wody wynosi przypuszczalnie 10-18 tysięcy lat. Zasoby eksploatacyjne ujęcia przyjęto w ilości $20,5 \mathrm{~m}^{3} / \mathrm{h}$ przy depresji $97,4 \mathrm{~m}$. Woda termalna nie jest wydobywana ze złoża.

\section{Cudzynowice}

Zasoby siarczkowych wód leczniczych o podwyższonej temperaturze w niecce miechowskiej po raz pierwszy udokumentowano w 2009 r. w złożu Busko-Północ (Giełżecka-Mądry i in., 2009). W 2015 r. wody o podobnej charakterystyce udostępniono do wydobywania otworem wiertniczym Cudzynowice GT-1 wykonanym do głębokości 750,0 m (Pacholewski i in., 2015). Poziom wodonośny tworzą piaski i piaskowce glaukonitowe kredy górnej (ce- nomanu). W złożu panują warunki artezyjskie. Zwierciadło wód podziemnych nawiercono na głębokości $667,0 \mathrm{~m}$, a poziom ustalony znajduje się $62,2 \mathrm{~m}$ ponad terenem. Zbiornik cenomański charakteryzuje się korzystnymi parametrami hydrogeologicznymi. Porowatość utworów wodonośnych mieści się w granicach 9-33\%, a ich przepuszczalność wynosi od 27,7 do 1380,0 mD. Średnia wartość współczynnika filtracji ujętego poziomu wodonośnego wynosi $2,3 \cdot 10^{-4} \mathrm{~m} / \mathrm{s}$. Ujęte wody scharakteryzowano jako $\mathrm{Cl}-\mathrm{SO}_{4}-\mathrm{Na}, \mathrm{I}, \mathrm{S}$ o mineralizacji ogólnej $15,1 \mathrm{~g} / \mathrm{dm}^{3}$ i temperaturze na wypływie $\mathrm{z}$ ujęcia $28,6^{\circ} \mathrm{C}$. Zawartość związków siarki (II) w wodzie wynosi 108,0 mg/dm ${ }^{3}$, a jodu $2,2 \mathrm{mg} / \mathrm{dm}^{3}$. Skład izotopowy wód nie był badany. Zasoby eksploatacyjne ujęcia przyjęto w wysokości $82,0 \mathrm{~m}^{3} / \mathrm{h}$ przy depresji 8,2 m. Woda termalna ze złoża jest wykorzystywana do celów grzewczych w miejscowym zespole szkół. Ma ona także potwierdzone właściwości lecznicze.

\section{Celejów}

Pierwsze, i jak dotychczas jedyne, złoże wód termalnych w południowo-wschodniej części niecki brzeżnej, w obrębie rowu lubelskiego, udokumentowano w 2015 r. (Biernat i in., 2015). Otworem wiertniczym Celejów GT-2 o głębokości całkowitej 1234,0 m (ostatecznej 1229,0 m) rozpoznano wody termalne w wapieniach i dolomitach jury górnej i środkowej. Utwory te zalegają w interwale 1023,0-1229,0 m i tworzą szczelinowy poziom wodonośny o miąższości 206,0 m i napiętym zwierciadle wody, stabilizującym się na głębokości 50,2 m. Utwory wodonośne charakteryzują się stosunkowo wysoką porowatością efektywną, dochodzącą do 30\%, i niską przepuszczalnością wynoszącą około $10 \mathrm{mD}$, maksymalnie $28 \mathrm{mD}$. Współczynnik filtracji warstwy wodonośnej mieści się w przedziale od 0,1 do $2,0 \cdot 10^{-6} \mathrm{~m} / \mathrm{s}$. Wodę ze złoża scharakteryzowano jako Cl-Na, I o mineralizacji ogólnej 45,5 g/ $\mathrm{dm}^{3}$. Temperatura wód na wypływie z ujęcia wynosiła maksymalnie $29,2^{\circ} \mathrm{C}$. Nie badano składu izotopowego wód. Zasoby eksploatacyjne ujęcia zatwierdzono w wysokości $28,0 \mathrm{~m}^{3} / \mathrm{h}$ przy depresji w otworze $92,1 \mathrm{~m}$. Woda termalna $\mathrm{z}$ otworu nie jest wydobywana.

\section{Konin}

W 2015 r. w niecce łódzkiej wykonano otwór wiertniczy Konin GT-1, którym udokumentowano rekordowo wysoką temperaturę wód podziemnych w Polsce, wynoszącą na wypływie z ujęcia $92,0^{\circ} \mathrm{C}$ (Myśliwiec i in., 2015). Otwór osiągnął głębokość 2660,0 m i został zakończony w iłowcach i mułowcach triasu. Wody termalne ujęto z poziomu wodonośnego jury dolnej, nawierconego na głębokości 2578,0 m. Zwierciadło wód stabilizuje się na głębokości 122,4 m. Poziom ten składa się z piaskowców drobno- i średnioziarnistych z iłowcami i mułowcami, a jego miąższość wynosi $63 \mathrm{~m}$. Współczynnik filtracji utworów wodonośnych wynosi $3,6 \cdot 10^{-5} \mathrm{~m} / \mathrm{s}$, a ich przepuszczalność zmienia się od 392 do $1809 \mathrm{mD}$ (średnio ok. $900 \mathrm{mD}$ ). Przeciętna porowatość całkowita piaskowców jury dolnej wynosi 16,5\%, natomiast porowatość efektywna 15,7\%. Pod względem hydrochemicznym wody te należą do typu Cl-Na, I o mineralizacji ogólnej 150,4 g/ $\mathrm{dm}^{3}$. Wody praktycznie nie zawierają trytu $(0,3 \mathrm{TU})$. Izotopy stabilne tlenu i wodoru występują w ilości: $\delta^{18} \mathrm{O}=-3,75 \%$ i $\delta^{2} \mathrm{H}=$ $-38,2 \%$. Woda nie zawiera komponenty zasilanej po 
1952 r., jednak określenie jej dokładnego „wieku” na podstawie przeprowadzonych badań jest niemożliwe. Prawdopodobnie jest to mieszanina wód infiltrujących w różnych epokach geologicznych. Zasoby eksploatacyjne otworu zatwierdzono w ilości $114,0 \mathrm{~m}^{3} / \mathrm{h}$ przy depresji $86,5 \mathrm{~m}$. Planuje się wykorzystywanie wód do celów grzewczych.

\section{Sieradz}

W 2018 r. na obszarze niecki łódzkiej otworem wiertniczym Sieradz GT-1 rozpoznano nowe złoże wód termalnych (Józefko i in., 2018). Otwór o głębokości 1505,0 m zakończono w stropowej części iłowców triasu górnego. Wody termalne ujęto z piaskowców kwarcowych i heterolitów piaskowcowo-mułowcowych jury dolnej zafiltrowanych w głębokości 1411,0-1483,0 m. Zwierciadło wód nawiercone na głębokości 1373,0 m stabilizuje się tuż pod powierzchnią terenu. Miąższość poziomu wodonośnego wynosi 126,0 m. Piaskowce jury dolnej w obrębie złoża charakteryzują się korzystnymi parametrami hydrogeologicznymi - wysokim współczynnikiem przepuszczalności i porowatością. Średnia wartość współczynnika filtracji utworów wodonośnych wynosi $1,1 \cdot 10^{-5} \mathrm{~m} / \mathrm{s}$. Typ chemiczny ujętych wód określono jako $\mathrm{Cl}-\mathrm{Na}$, a ich mineralizacja ogólna wynosi $2,6 \mathrm{~g} / \mathrm{dm}^{3}$. Temperatura wody na wypływie $\mathrm{z}$ ujęcia dochodzi maksymalnie do $51,8^{\circ} \mathrm{C}$. Badania składu izotopowego wody nie wykazały obecności trytu i radiowęgla, a pozostałe oznaczone izotopy występowały w ilości: $\delta^{18} \mathrm{O}=-10,47 \%$ o, $\delta^{2} \mathrm{H}=-75,3 \%$ i $\delta^{13} \mathrm{C}=-11,6 \%$. Przypuszczalny „wiek” wody jest określany na 27-33 tysiące lat. Zasoby eksploatacyjne ujęcia ustalono w wysokości $249,0 \mathrm{~m}^{3} / \mathrm{h}$ przy depresji 75,0 m. Wody termalne ze złoża mają być przeznaczone na cele ciepłownicze.

\section{Turek}

W odległości ok. $25 \mathrm{~km}$ na południowy zachód od Koła w 2019 r. wykonano otwór wiertniczy Turek GT-1 (Kukuła i in., 2019b). Udokumentowano nim kolejne, po Łodzi, Uniejowie, Poddębicach, Koninie i Sieradzu, złoże wód termalnych w niecce łódzkiej, będącej jednym z najbardziej perspektywicznych regionów w Polsce do zagospodarowania zasobów geotermalnych. Wiercenie otworu zakończono na głębokości 2169,0 m w mułowcach triasu górnego. Ostatecznie głębokość otworu, z powodu częściowego zasypu, wynosi $2151,0 \mathrm{~m}$. Wody termalne ujęto z utworów jury dolnej wykształconych jako drobnoziarniste piaskowce kwarcowe oraz heterolity piaskowcowo-mułowcowe z nielicznymi wkładkami mułowców. Miąższość poziomu wodonośnego wynosi $48,3 \mathrm{~m}$, a budujące go utwory charakteryzują się dobrymi właściwościami zbiornikowymi - współczynnik porowatości osiąga 13,7\%, a współczynnik filtracji wynosi $2,7 \cdot 10^{-6} \mathrm{~m} / \mathrm{s}$. Zwierciadło wody, nawiercone na głębokości $2100,5 \mathrm{~m}$, stabilizuje się na głębokości $115,4 \mathrm{~m}$. Z odcinka zafiltrowanego w interwale 2101,9-2144,1 m uzyskano wody typu Cl-Na, I, Fe o mineralizacji ogólnej 132,2-132,9 g/ $\mathrm{dm}^{3}$ i temperaturze osiągającej na wypływie $\mathrm{z}$ ujęcia maksymalnie $77,9^{\circ} \mathrm{C}$. Badania składu izotopowego wykazały, że wody te nie zawierają trytu $(0,1 \mathrm{TU})$, a zawartość izotopów stabilnych tlenu i wodoru wynosi w nich: $\delta^{18} \mathrm{O}=-2,53 \%$ i $\delta^{2} \mathrm{H}=$ $-33,8 \%$. Interpretacja powyższych danych jest niejednoznaczna i nie pozwala na określenie ,wieku” wody. Zasoby eksploatacyjne ujęcia wynoszą $54,0 \mathrm{~m}^{3} / \mathrm{h}$ przy depresji
167,0 m. W przyszłości woda z otworu ma być wydobywana na potrzeby ciepłownicze.

\section{Sochaczew}

Kolejnym otworem wiertniczym wykonanym w 2018 r. w południowej części niecki warszawskiej, w obrębie bloku Grodziska Mazowieckiego, jest otwór Sochaczew GT-1 (Kapuściński i in., 2019b). Wiercenie zakończono na głębokości 1540,0 m w drobno- i średnioziarnistych piaskowcach kwarcowych z przewarstwieniami mułowców, iłowców i margli kredy dolnej. Są to utwory kruche, słabo zwięzłe, miejscami zawierające okruchy węgla brunatnego. Udział serii piaskowcowych w profilu wynosi ok. $43 \%$. Utwory kredy dolnej w rejonie Sochaczewa tworzą zbiornik wód termalnych o bardzo dobrych właściwościach kolektorskich, przejawiających się wysoką porowatością (25-31\%) oraz dużą przepuszczalnością (715-2085 mD). Współczynnik filtracji utworów wodonośnych wynosi $5,1 \cdot 10^{-5} \mathrm{~m} / \mathrm{s}$. Zwierciadło wód termalnych nawiercono na głębokości 1360,0 m. W złożu panują warunki artezyjskie, zwierciadło wody stabilizuje się $22,3 \mathrm{~m}$ ponad powierzchnią terenu. Wody ujęte $\mathrm{z}$ głębokości 1351,2-1486,5 m należą do typu $\mathrm{Cl}-\mathrm{HCO}_{3}-\mathrm{Ca}-\mathrm{Na}$, a ich mineralizacja ogólna wynosi $0,96 \mathrm{~g} / \mathrm{dm}^{3}$. Temperatura wody na wypływie $\mathrm{z}$ ujęcia osiąga maksymalnie $44,3^{\circ} \mathrm{C}$. Woda $\mathrm{z}$ otworu nie zawiera trytu, a stężenie izotopów stabilnych wynosi: $\delta^{18} \mathrm{O}=$ $-10,46 \%$ i $\delta^{2} \mathrm{H}=-76,9 \%$. Prawdopodobnie woda trafiła do systemu wodonośnego w okresie schyłkowym ostatniego zlodowacenia. Zasoby eksploatacyjne ujęcia zatwierdzono w wysokości $180,0 \mathrm{~m}^{3} / \mathrm{h}$ przy depresji $18,0 \mathrm{~m}$. Wody termalne ze złoża mają być przeznaczone do celów energetycznych.

\section{Wręcza}

W odległości ok. 5 km na północny-zachód od Mszczonowa, w strefie przejściowej pomiędzy synklinorium brzeżnym (niecką warszawską) a antyklinorium środkowopolskim, w 2018 r. wykonano otwór wiertniczy Wręcza GT-1 (Kapuściński i in., 2019a). Otworem o głębokości 1668,0 m rozpoznano złoże wód termalnych w utworach kredy dolnej, wykształconych w postaci trzech serii drobno-, średnio- i gruboziarnistych piaskowców kwarcowych rozdzielonych iłowcami, mułowcami i marglami. Do eksploatacji udostępniono interwał głębokościowy 1531,01643,0 m. Poziom wodonośny odznacza się bardzo dobrymi właściwościami zbiornikowymi. Porowatość efektywna piaskowców mieści się w przedziale 27-31\%, a współczynnik filtracji osiąga wartość $6,7 \cdot 10^{-5} \mathrm{~m} / \mathrm{s}$. Ujęte wody reprezentują typ chemiczny $\mathrm{HCO}_{3}-\mathrm{Ca}-\mathrm{Mg}$ i charakteryzują się niską mineralizacją ogólną, wynoszącą zaledwie $0,42 \mathrm{~g} / \mathrm{dm}^{3}$. Temperatura wody na wypływie $\mathrm{z}$ ujęcia wynosi $40,1^{\circ} \mathrm{C}$. Wody o podobnych parametrach typu $\mathrm{HCO}_{3}-$ $\mathrm{Ca}-\mathrm{Na}-(\mathrm{Mg})$ są znane $\mathrm{z}$ piaskowców i mułowców kredy dolnej w pobliskim Mszczonowie, gdzie są wydobywane z głębokości 1602,5-1714,0 m. Próbkę wody poddano badaniom składu izotopowego i uzyskano następujące wyniki: tryt $=0,6 \mathrm{TU}, \delta^{18} \mathrm{O}=-10,25 \%$, $\delta^{2} \mathrm{H}=-74,6 \%$. Wody te infiltrowały do systemu wodonośnego przed 1952 r., prawdopodobnie pod koniec ostatniego zlodowacenia. Zasoby eksploatacyjne ujęcia wynoszą $150,0 \mathrm{~m}^{3} / \mathrm{h}$ przy depresji w wygrzanym otworze $29,7 \mathrm{~m}$. Wody termalne ze złoża są wykorzystywane w parku wodnym Suntago. 


\section{Koło}

Koło jest położone w niecce mogileńsko-łódzkiej, w strefie tektonicznej Gopło-Ponętów-Pabianice. Wgłębna budowa geologiczna i warunki hydrogeologiczne panujące w mezozoicznych poziomach wodonośnych tego obszaru są stosunkowo dobrze rozpoznane. Rejon Koła był uznawany za obszar perspektywiczny występowania wód termalnych przydatnych do ogrzewania, co zostało potwierdzone wykonanym w 2018 r. w miejscowości Chojny otworem wiertniczym Koło GT-1 (Kukuła i in., 2019a). Otwór zakończono na głębokości 3905,0 m w iłowcach triasu górnego, a następnie zlikwidowano jego spód do głębokości 2815,0 m z uwagi na brak potencjału złożowego piaskowców i mułowców jury dolnej. Wody termalne ujęto $\mathrm{w}$ interwale 2576,0-2796,7 m z dolnokredowych piaskowców i piaszczystych mułowców oraz heterolitów piaskowcowo-mułowcowych zaliczanych do formacji mogileńskiej (alb środkowy-barrem) i piaskowców formacji bodzanowskiej (walanżyn dolny) (ryc. 4). Zwierciadło wody, nawiercone na głębokości 2565,0 m, ustabilizowało się 76,7 m pod powierzchnią terenu. Porowatość efektywna ujętych utworów zmienia się od 9,6 do 17,8\%, przepuszczalność mieści się w zakresie 4,4-425,2 mD, a średnia wartość współczynnika filtracji wynosi $3,6 \cdot 10^{-6} \mathrm{~m} / \mathrm{s}$. Najkorzystniejszymi parametrami hydraulicznymi odznacza się piaskowcowe ogniwo kruszwickie formacji mogileńskiej, nawiercone na głębokości 2566,0-2708,0 m. Ujęte wody termalne reprezentują typ $\mathrm{Cl}-\mathrm{Na}, \mathrm{I},(\mathrm{Fe})$, a ich mineralizacja ogólna wynosi 93,5-94,9 g/ $\mathrm{dm}^{3}$. Temperatura wody na wypływie $\mathrm{z}$ ujęcia osiąga maksymalnie $84,3^{\circ} \mathrm{C}$. Woda prawie nie zawiera trytu $(0,2 \mathrm{TU})$, a zawartość izo-

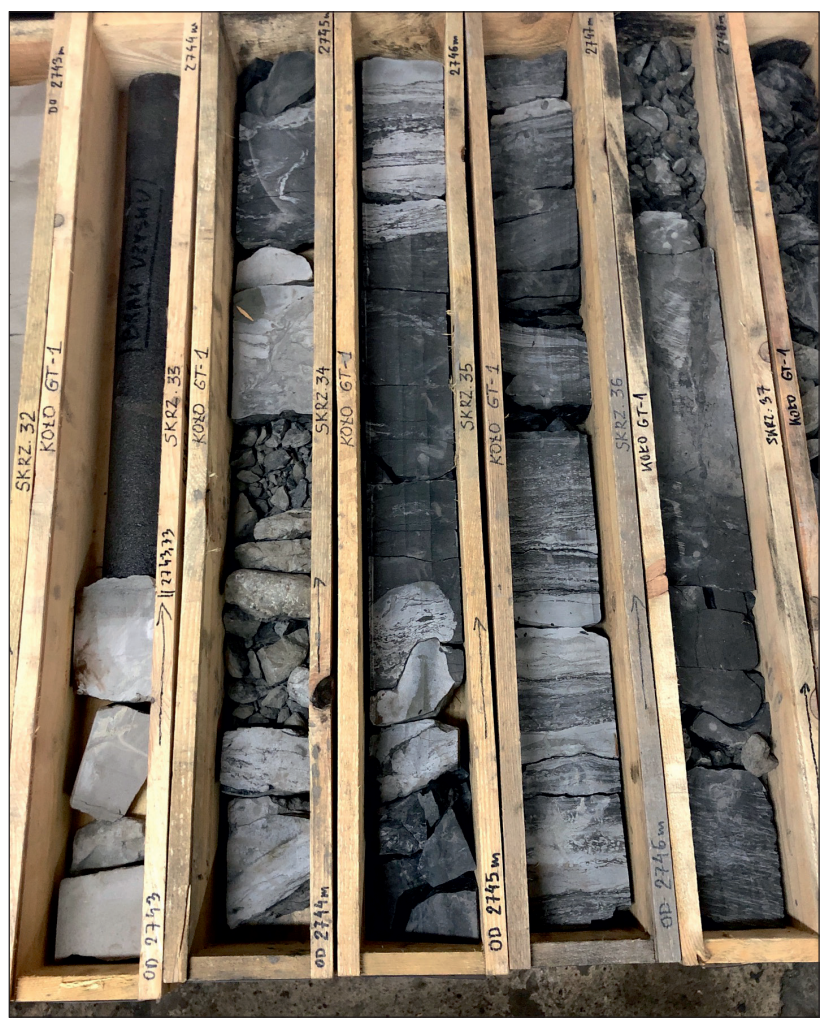

Ryc. 4. Rdzeń wiertniczy z poziomu wodonośnego kredy dolnej ujętego otworem Koło GT-1. Fot. I. Gryszkiewicz

Fig. 4. Drill core from the Lower Cretaceous aquifer in the Koło GT-1 borehole. Photo by I. Gryszkiewicz topów stabilnych tlenu i wodoru wynosi: $\delta^{18} \mathrm{O}=-6,31 \%$, $\delta^{2} \mathrm{H}=-48,2 \%$. Wyniki składu izotopowego wody wskazują na jej przedczwartorzędowe pochodzenie. Zasoby eksploatacyjne otworu ustalono w ilości $257,0 \mathrm{~m}^{3} / \mathrm{h}$ przy depresji 120,1 m. Wody termalne ze złoża mają być głównie przeznaczone na cele ciepłownicze.

\section{Jachranka}

W 2019 r. w podwarszawskiej Jachrance wykonano dwa otwory wiertnicze: Jachranka GT-1 o głębokości $1780,5 \mathrm{~m}$ i Jachranka GT-2K (otwór kierunkowy) o długości 2150,0 m (Bielec, Operacz, 2020). Rozpoznano nimi utwory mezozoiczne południowo-wschodniej części niecki warszawskiej, w szczególności kredy dolnej i jury dolnej. Przed wykonaniem otworów w Jachrance w obrębie niecki brzeżnej w rejonie Warszawy złoża wód termalnych udokumentowano w Mszczonowie, Wręczy, Sochaczewie (w poziomie wodonośnym kredy dolnej) i Skierniewicach (w poziomie wodonośnym jury dolnej). Po udokumentowaniu zasobów Jachranka stała się najdalej położonym na wschód złożem wód termalnych w nizinnej części Polski. W otworze GT-1 z utworów kredy dolnej w interwale 931,0-973,0 m uzyskano wypływ wody w maksymalnej ilości $90,4 \mathrm{~m}^{3} / \mathrm{h}$ i temperaturze osiągającej na powierzchni $22,6^{\circ} \mathrm{C}$. Złoże wód termalnych udokumentowano w niżejległym porowym kompleksie jury dolnej, którego strop nawiercono na głębokości 1524,0 m (1508,4 m w otworze GT-2K). Miąższość utworów dolnojurajskich wynosi ok. 230 (250 m w otworze GT-2K). Pod względem litologicznym są to głównie piaskowce o różnej granulacji i iłowce. Udział piaskowców w całym profilu jury dolnej wynosi ok. 70\%. Współczynnik porowatości piaskowców wynosi 27\%, a ich średnia przepuszczalność 2183 mD. Współczynnik filtracji utworów wodonośnych osiąga wartość od $1,3 \cdot 10^{-5} \mathrm{~m} / \mathrm{s}$ (otw. GT-1) do $3,4 \cdot 10^{-5} \mathrm{~m} / \mathrm{s}$ (otw. GT- $2 \mathrm{~K}$ ). Ujęte wody termalne scharakteryzowano jako $\mathrm{Cl}-\mathrm{Na}$, I, (Fe) o mineralizacji ogólnej wynoszącej od $67,6 \mathrm{~g} / \mathrm{dm}^{3}$ w otworze GT-2K do $77,4 \mathrm{~g} / \mathrm{dm}^{3}$ w otworze GT-1 i temperaturze osiągającej na wypływie z ujęć maksymalnie: $42,5^{\circ} \mathrm{C}$ (otw. GT-2K) i 43, $2^{\circ} \mathrm{C}$ (otw. GT-1). Woda $\mathrm{z}$ otworu Jachranka GT-1 nie zawiera trytu, a stężenie izotopów stabilnych tlenu $\left(\delta^{18} \mathrm{O}\right)$ i wodoru $\left(\delta^{2} \mathrm{H}\right)$ wynosi odpowiednio $-5,07 \%$ i $-42,6 \%$. Dla wody z otworu Jachranka GT-2K uzyskano następujące wyniki: tryt $=0,3 \mathrm{TU}, \delta^{18} \mathrm{O}=$ $-5,22 \%, \delta^{2} \mathrm{H}=-43,0 \%$. Skład izotopowy wody wskazuje na jej pochodzenie infiltracyjne, przy czym zasilanie odbywało się prawdopodobnie przed czwartorzędem. Dokładniejsze określenie ,wieku” wody na obecnym etapie jest niemożliwe. Zasoby eksploatacyjne dwuotworowego ujęcia zatwierdzono w ilości $201,0 \mathrm{~m}^{3} / \mathrm{h}$, w tym dla otworu GT-1 $188,5 \mathrm{~m}^{3} / \mathrm{h}$ przy depresji $12,5 \mathrm{~m}$, zaś dla otworu GT-2K $201,0 \mathrm{~m}^{3} / \mathrm{h}$ przy depresji $14,9 \mathrm{~m}$. Zgodnie z założeniami projektowymi wody termalne mają być wykorzystywane w zespole rekreacyjno-uzdrowiskowym, składającym się $\mathrm{z}$ basenów termalnych, parku wodnego oraz tężni solankowej.

\section{Tomaszów Mazowiecki}

W 2019 r. wykonano otwór wiertniczy Tomaszów Mazowiecki GT-1 (Kapuściński i in., 2019c). Wyniki wiercenia potwierdziły, że obszar niecki łódzkiej jest rejonem perspektywicznym występowania wód termalnych. Wier- 
cenie otworu zakończono na głębokości 1672,0 m w iłowcach z przewarstwieniami mułowców triasu górnego. Wody termalne ujęto z utworów jury dolnej wykształconych jako drobnoziarniste piaskowce kwarcowe z przewarstwieniami iłowców i mułowców. Miąższość poziomu wodonośnego wynosi 128,0 m, a budujące go utwory charakteryzują się dobrymi właściwościami zbiornikowymi średni współczynnik porowatości wynosi 16,1\%, a średnia przepuszczalność $98,7 \mathrm{mD}$. Brak jest danych dotyczących wartości współczynnika filtracji. Zwierciadło wody nawiercono w stropie utworów jury dolnej na głębokości 1437,0 m. Otwór zafiltrowano w interwale 1430,5-1562,9 m przy ostatecznej głębokości otworu wynoszącej 1577,0 m. Uzyskane wody reprezentują typ $\mathrm{Cl}-\mathrm{HCO}_{3}-\mathrm{Na}$ o mineralizacji ogólnej $0,5 \mathrm{~g} / \mathrm{dm}^{3}$ i temperaturze osiągającej na wypływie z ujęcia maksymalnie $41,7^{\circ} \mathrm{C}$. Badania składu izotopowego wykazały, że wody te nie zawierają trytu (0,0 TU), a zawartość pozostałych izotopów wynosi: $\delta^{18} \mathrm{O}=-11,02 \%$, $\delta^{2} \mathrm{H}=-78,3 \%$ i $\delta^{13} \mathrm{C}=-15,0 \%$. Na podstawie interpretacji danych izotopowych ,wiek" wody szacuje się na ponad 35 tysięcy lat. Zasoby eksploatacyjne ujęcia wynoszą $80,0 \mathrm{~m}^{3} / \mathrm{h}$ przy depresji $190,0 \mathrm{~m}$. Planuje się, że woda termalna będzie wykorzystywana do celów ciepłowniczych.

\section{WNIOSKI}

Rozpoznanie głębokich systemów wodonośnych jest możliwe dzięki licznym otworom wiertniczym wykonywanym od lat 50. XX w. przez przemysł naftowy oraz PIG-PIB. Jakość wyników uzyskanych z opróbowań hydrogeologicznych przeprowadzonych w tych otworach, zwłaszcza tych starszych, jest jednak dalece niewystarczająca do pełnej oceny warunków hydrodynamicznych i hydrochemicznych panujących w badanych poziomach wodonośnych. Stosowane niegdyś metody badawcze (rurowe próbniki złoża, łyżkowanie, wytłaczanie kompresorem) nie pozwalają na wiarygodną ocenę parametrów filtracyjnych ośrodka skalnego, a uzyskane podczas badań próbki wody często wykazują znaczną kontaminację płuczką wiertniczą, co uzyskane wyniki czyni mało wiarygodnymi. Dodatkowo zbiór danych hydrogeologicznych, choć liczny, nie jest w pełni reprezentatywny. Opróbowania głębokich otworów wiertniczych były bowiem przeprowadzane przede wszystkim w poziomach perspektywicznych dla zachowania się złóż węglowodorów, na ogół nie będących istotnymi poziomami wodonośnymi. Wynika to z faktu, że w głównej mierze były to otwory poszukiwawcze za złożami węglowodorów. Pełniejszym opróbowaniem charakteryzują się otwory badawczo-strukturalne, wykonywane głównie przez PIG-PIB w celu rozpoznania wgłębnej budowy geologicznej kraju, jednak ich liczba jest stosunkowo niewielka. W otworach tych były przewiercane poziomy wodonośne mogące mieć zastosowanie w geotermii lub balneoterapii.

Nowe inwestycje geotermalne w zasadniczy sposób zmieniają obraz rozpoznania głębokich systemów wodonośnych, zwłaszcza na obszarze Niżu Polskiego. Otwory geotermalne są bowiem otworami hydrogeologicznymi opróbowanymi w szerokim zakresie, umożliwiającym m.in. określenie ich zasobów eksploatacyjnych. W zakresie hydrodynamiki systemów wodonośnych otwory te do- starczają przede wszystkim informacji o wartości współczynnika filtracji utworów budujących warstwy wodonośne oraz o głębokości występowania powierzchni piezometrycznej (tab. 1). Dane te pochodzą z wielostopniowych próbnych pompowań pomiarowych lub testów hydrodynamicznych, co sprawia, że stanowią cenne i wiarygodne źródło informacji o warunkach ciśnieniowych oraz kierunku i prędkości przepływu wód podziemnych. Dodatkową zaletą badań hydrodynamicznych jest ich prowadzenie do momentu uzyskania czystej wody złożowej, a więc pobrane na ich zakończenie próbki wody nie wykazują zanieczyszczeń powstałych na etapie wiercenia. Analizy laboratoryjne wód termalnych, w porównaniu do wyników badań z otworów badawczych, charakteryzują się szerokim zakresem oznaczanych składników, obejmującym nie tylko główne aniony i kationy, lecz także długą listę mikroelementów (m.in. składniki swoiste, metale ciężkie), składniki niezdysocjowane (kwas metaborowy, kwas metakrzemowy), umożliwiającym sporządzenie poprawnego bilansu jonowego wody i określenie jej mineralizacji ogólnej. Wyniki oznaczeń zawierają także szereg właściwości fizycznych wody, takich jak temperatura, przewodność elektrolityczna właściwa i odczyn. Wyniki badań właściwości fizyczno-chemicznych wód termalnych służą nie tylko do określenia typu chemicznego wód. Mogą być także wykorzystywane w modelowaniu hydrogeochemicznym do oceny genezy tych wód. Określenie pochodzenia wód termalnych i stopnia odnawialności ich zasobów jest także możliwe dzięki badaniom ich składu izotopowego. Określenie zawartości izotopów stabilnych tlenu i wodoru oraz zawartości trytu jest obecnie standardem w praktyce dokumentowania zasobów eksploatacyjnych ujęć wód termalnych (tab. 2). Pozwala określić czas przebywania wód w ośrodku skalnym (ich ,wiek”), a także wskazać przypuszczalne miejsce i czas infiltracji wód do systemu wodonośnego.

Wydaje się, że przy użyciu nowych danych hydrogeologicznych celowym jest przedstawienie regionalnej syntezy warunków hydrogeologicznych panujących w głębokich systemach wodonośnych, polegającej na reambulacji najważniejszych dla omawianego zagadnienia prac naukowych (Bojarski, 1996; Górecki, 2006). Istnieje także potrzeba opracowania nowej regionalizacji hydrogeologicznej wód podziemnych zaliczonych do kopalin, w tym wód termalnych, opartej przede wszystkim na kryteriach hydrodynamicznych, a nie, jak dotychczas, strukturalnych. Zbiór wiarygodnych i pełnych danych z opróbowań hydrogeologicznych wierceń geotermalnych pozwala na podjęcie takiej próby. Perspektywa transformacji energetycznej kraju pociąga za sobą konieczność zwiększenia udziału odnawialnych źródeł energii w miksie energetycznym. W efekcie lista zatwierdzonych projektów robót geologicznych na kolejne otwory geotermalne jest długa. Zrealizowanie planowanych inwestycji może stanowić kolejny krok ku zmniejszeniu nadal dużego ryzyka geologicznego inwestycji geotermalnych, co pokazują przykłady braku dopływu wód do otworów geotermalnych w Krynicy-Zdroju (Bystroń i in., 2011), Lądku-Zdroju (Rasała i in., 2019), Dębicy (Kukuła i in., 2020a) i Sękowej (Kukuła i in., 2020b). Optymalizacja lokalizacji nowych przedsięwzięć pod kątem warunków hydrodynamicznych wydaje się więc kluczowym czynnikiem warunkującym powodzenie przedsięwzięć geotermalnych. 


\section{LITERATURA}

BIELEC B., OPERACZ A. 2020 - Dokumentacja hydrogeologiczna ustalająca zasoby eksploatacyjne ujęcia wód termalnych z utworów jury dolnej w Jachrance (otwory: Jachranka GT-1 i Jachranka GT-2K). Agnieszka Operacz VENA, Kraków. Niepublikowane. Narod. Arch. Geol. PIG-PIB, Warszawa. Nr inw. 6962/2020.

BIERNAT H., KAPUŚCIŃSKI J., NIEWIAROWICZ J., MARTYKA P. 2011a - Dokumentacja hydrogeologiczna ustalająca zasoby eksploatacyjne ujęcia wód termalnych w Kleszczowie wraz z określeniem warunków wtłaczania wód wykorzystanych do górotworu. Przeds. Geol. Polgeol S.A., Warszawa. Niepublikowane. Narod. Arch. Geol. PIG-PIB, Warszawa. Nr inw. 2565/2012

BIERNAT H., KAPUŚCIŃSKI J., NIEWIAROWICZ J., NOWAK K., MARTYKA P. 2011b - Dokumentacja hydrogeologiczna ustalająca zasoby eksploatacyjne ujęcia wód termalnych w Toruniu wraz z określeniem warunków wtłaczania wód wykorzystanych do górotworu (otwór eksploatacyjny - Toruń TG-1, otwór chłonny - Toruń TG-2). Przeds. Geol. Polgeol S.A., Warszawa. Niepublikowane. Narod. Arch. Geol. PIG-PIB, Warszawa. Nr inw. 116/2012.

BIERNAT H., KAPUŚCIŃSKI J., PIJEWSKI G., SZYMAŃSKA E., NOWAK K. 2011c - Dokumentacja hydrogeologiczna ustalająca zasoby eksploatacyjne ujęcia wód termalnych z utworów jury dolnej w otworze Tarnowo Podgórne GT-1. Przeds. Geol. Polgeol S.A., Warszawa. Niepublikowane. Narod. Arch. Geol. PIG-PIB, Warszawa. Nr inw. 114/2012. BIERNAT H., KAPUŚCIŃSKI J., SZYMAŃSKA E., WIŚNIEWSKA M. 2011d - Dokumentacja hydrogeologiczna ustalająca zasoby eksploatacyjne ujęcia wód termalnych $\mathrm{z}$ utworów jury dolnej w otworze Lidzbark Warmiński GT-1. Przeds. Geol. Polgeol S.A., Warszawa. Niepublikowane. Narod. Arch. Geol. PIG-PIB, Warszawa. Nr inw. 525/2012.

BIERNAT H., KAPUŚCIŃSKI J., PIJEWSKI G., MARTYKA P., BARSZCZEWSKA M., NOWAK K. 2012 - Dokumentacja hydrogeologiczna ustalająca zasoby eksploatacyjne ujęcia wód termalnych z utworów jury dolnej w otworze Trzęsacz GT-1. Przeds. Geol. Polgeol S.A., Warszawa. Niepublikowane. Narod. Arch. Geol. PIG-PIB, Warszawa. Nr inw. 3860/2013.

BIERNAT H., MARTYKA P., KOTKO D., PAJAK Ł., CZAPLA K., ZWIERZYŃSKI M. 2015 - Dokumentacja hydrogeologiczna ustalająca zasoby eksploatacyjne ujęcia wód termalnych z utworów jury górnej i jury środkowej w Celejowie. Przeds. Geol. Polgeol S.A., Warszawa. Niepublikowane. Narod. Arch. Geol. PIG-PIB, Warszawa. Nr inw. $3535 / 2015$.

BOJARSKI L. (red.) 1996 - Atlas hydrochemiczny i hydrodynamiczny paleozoiku i mezozoiku oraz ascenzyjnego zasolenia wód podziemnych na Niżu Polskim w skali 1: 1000 000. Państw. Inst. Geol., Warszawa.

BYSTROŃ K., BIELEC B., OSZCZYPKO N., KURSA G., WRONKA A., MALINA L., SZELIGA W., SPINCZYK A., TOMASZEWSKA B., BUJAKOWSKI W., HOŁUJUCH G., CHOJNACKI S. 2011 - Dokumentacja z wykonania prac geologicznych w celu poszukiwania i rozpoznawania złoża wód termalnych otworem Czarny Potok GT-1 niekończąca się udokumentowaniem zasobów w miejscowości Krynica-Zdrój wraz z opracowaniem badań geofizycznych. Geokrak Sp. z o.o., Kraków. Niepublikowane. Narod. Arch. Geol. PIG-PIB, Warszawa. Nr inw. 96/2012. BYSTROŃ K., GUTY Ł., DŁUGOSZ P. 2020 - Dodatek nr 1 do dokumentacji hydrogeologicznej ustalającej zasoby eksploatacyjne ujęcia wód termalnych w Toruniu wraz z określeniem warunków wtłaczania wód wykorzystanych do górotworu (otwór eksploatacyjny - Toruń TG-1, otwór chłonny - Toruń TG-2). Pro-Invest Solutions Sp. z o.o. Sp. k., Kraków. Niepublikowane. Narod. Arch. Geol. PIG-PIB, Warszawa. Nr inw. 6550/2020.

GIEŁŻECKA-MADRY D., KASELA T., LISIK R., ZARDZEWIAŁY M., GRZEGORZEWSKI G., GRZEGORZEWSKA I., MYŚLIWIEC A., BĄK M., RABIEJ L. 2009 - Dokumentacja hydrogeologiczna ustalająca zasoby eksploatacyjne ujęcia leczniczych wód siarczkowych „Busko C-1" z utworów kredy górnej w miejscowości Busko-Zdrój. Hydrogeotechnika Sp. z o.o., Kielce. Niepublikowane. Narod. Arch. Geol. PIG-PIB, Warszawa. Nr inw. 2248/2010.

GÓRECKI W. (red.) 2006 - Atlas zasobów geotermalnych formacji mezozoicznej na Niżu Polskim. Akad. Górn.-Hut., Kraków.

JÓZEFKO I., KUKUŁA M., BYSTROŃ K., GUTY Ł., KOSIEK K. 2018 - Dokumentacja hydrogeologiczna ustalająca zasoby eksploatacyjne ujęcia wód termalnych Sieradz GT-1 w Sieradzu. Pro-Invest Solutions Sp. z o.o. Sp. k., Kraków; PBG Geoprofil I. Józefko, M. Kukuła s.c., Kraków. Niepublikowane. Narod. Arch. Geol. PIG-PIB, Warszawa. Nr inw. 1826/2019. KAPUŚCIŃSKI J., WAGNER J., RENOWSKI M., NOGA B. 2019a Dokumentacja hydrogeologiczna ustalająca zasoby eksploatacyjne ujęcia wód termalnych z utworów kredy dolnej ujętych otworem Wręcza GT-1 w miejscowości Wręcza, gmina Mszczonów. HPC Polgeol S.A., Warszawa. Niepublikowane. Narod. Arch. Geol. PIG-PIB, Warszawa. Nr inw. $3303 / 2019$.
KAPUŚCIŃSKI J., WAGNER J., RENOWSKI M., NOGA B. 2019 b Dokumentacja hydrogeologiczna ustalająca zasoby eksploatacyjne ujęcia wód termalnych z utworów kredy dolnej ujętych otworem Sochaczew GT-1. HPC Polgeol S.A., Warszawa. Niepublikowane. Narod. Arch. Geol. PIG-PIB, Warszawa. Nr inw. 5657/2019.

KAPUŚCIŃSKI J., BYSTROŃ K., GUTY Ł., WAGNER J., RENOWSKI M., NOGA B., DŁUGOSZ P. 2019c - Dokumentacja hydrogeologiczna ustalająca zasoby eksploatacyjne ujęcia wód termalnych z utworów jury dolnej ujętych otworem Tomaszów Mazowiecki GT-1. HPC Polgeol S.A., Warszawa; Pro-Invest Solutions Sp. z o.o. Sp. k., Kraków. Niepublikowane. Narod. Arch. Geol. PIG-PIB, Warszawa. Nr inw. 4257/2021.

KUKUŁA M., BYSTROŃ K., GUTY Ł., CZELUŚNIAK P. 2020a - Dokumentacja prac geologicznych niekończących się udokumentowaniem zasobów wód podziemnych polegających na poszukiwaniu wód termalnych otworem Dębica GT-1 w miejscowości Dębica. Pro-Invest Solutions Sp. z o.o. Sp. k., Kraków; PBG Geoprofil M. Kukuła s.c., Kraków. Niepublikowane. Narod. Arch. Geol. PIG-PIB, Warszawa. Nr inw. 2311/2020.

KUKUŁA M., BYSTROŃ K., GUTY Ł., KOSIEK K. 2020b - Dokumentacja prac geologicznych niekończących się udokumentowaniem zasobów wód podziemnych polegających na poszukiwaniu wód termalnych otworem Sękowa GT-1 w miejscowości Sękowa. Pro-Invest Solutions Sp. z o.o. Sp. k., Kraków; PBG Geoprofil M. Kukuła s.c., Kraków. Niepublikowane. Narod. Arch. Geol. PIG-PIB, Warszawa. Nr inw. 393/2021.

KUKUŁA M., BYSTROŃ K., GUTY Ł., KOSIEK K., DŁUGOSZ P. 2019a - Dokumentacja hydrogeologiczna ustalająca zasoby eksploatacyjne ujęcia wód termalnych Koło GT-1 w miejscowości Chojny, gmina Koło. G-Drilling S.A., Warszawa. Niepublikowane. Narod. Arch. Geol. PIG-PIB, Warszawa. Nr inw. 4370/2020.

KUKUŁA M., KAPUŚCIŃSKI J., BYSTROŃ K., GUTY Ł., DŁUGOSZ P., NOGA B. 2019b - Dokumentacja hydrogeologiczna ustalająca zasoby eksploatacyjne ujęcia wód termalnych Turek GT-1 w Turku. UOS Drilling S.A., Warszawa. Niepublikowane. Narod. Arch. Geol. PIG-PIB, Warszawa. Nr inw. 34/2020.

ŁUKACZYŃSKI I., POLACZEK P. 2014a - Dokumentacja hydrogeologiczna ustalająca zasoby eksploatacyjne ujęcia wód termalnych otworem Karpniki KT-1 w Karpnikach k/Jeleniej Góry. Nowe Przeds. Geol. s.c., Częstochowa. Niepublikowane. Narod. Arch. Geol. PIG-PIB, Warszawa. $\mathrm{Nr}$ inw. 38/2015.

ŁUKACZYŃSKI I., POLACZEK P. 2014b - Dokumentacja hydrogeologiczna ustalająca zasoby eksploatacyjne ujęcia wód termalnych otworem ST-1 w Staniszowie k/Jeleniej Góry. Nowe Przeds. Geol. s.c., Częstochowa. Niepublikowane. Narod. Arch. Geol. PIG-PIB, Warszawa. Nr inw. $39 / 2015$.

MYŚLIWIEC A., SZCZEŚNIAK-SZLAGOWSKA A., ZWIERZCHOWSKA T., MIELNICZUK M., MIELNICZUK W., ZIĘBA M. 2015 - Dokumentacja hydrogeologiczna ustalająca zasoby eksploatacyjne wód termalnych z utworów jury dolnej ujętych otworem Konin GT-1 w Koninie (Wyspa „Pociejewo”). Przeds. Geol Sp. z o.o., Kielce. Niepublikowane. Narod. Arch. Geol. PIG-PIB, Warszawa. Nr inw. 1817/2016.

PACHOLEWSKI A., WIKTOROWICZ B., KOS M., MŁYŃCZAK T., LIPIEC I., FELTER A., SOCHA M. 2015 - Dokumentacja hydrogeologiczna ustalająca zasoby eksploatacyjne ujęcia wód termalnych i leczniczych Cudzynowice GT-1 z utworów górnej kredy. Państw. Inst. Geol. PIB, Kielce. Niepublikowane. Narod. Arch. Geol. PIG-PIB, Warszawa. $\mathrm{Nr}$ inw. 4440/2015.

RASAŁA M., CIĘŻKOWSKI W., WAৃSIK M., KIEŁCZAWA B. 2019 Dokumentacja geologiczna z wykonania prac geologicznych niekończących się udokumentowaniem zasobów złoża kopaliny w związku z wykonaniem otworu poszukiwawczego za wodami termalnymi LZT-1 w Ląku-Zdroju. Hydro-Geo-Term M. Rasała, Poznań. Niepublikowane. Narod. Arch. Geol. PIG-PIB, Warszawa. Nr inw. 9119/2019.

ROZPORZĄDZENIE MINISTRA ŚRODOWISKA Z DNIA 18 listopada 2016 r. w sprawie dokumentacji hydrogeologicznej i dokumentacji geologiczno-inżynierskiej. Dz.U. z 2016 poz. 2033.

SOKOŁOWSKI J., SKRZYPCZYK L. 2021 - Solanki, wody lecznicze i termalne. $W$ : Bilans zasobów złóż kopalin w Polsce wg stanu na 31 XII 2020 r. (red. M. Szuflicki i in.). Państw. Inst. Geol. - PIB, Warszawa: 488-505.

TADYCH J., RASAŁA M., TADYCH A. 2010 - Dokumentacja hydrogeologiczna ustalająca zasoby eksploatacyjne ujęcia wód termalnych Poddębice GT-2 w miejscowości Poddębice. Thermhouse J. Tadych, Inowrocław. Niepublikowane. Narod. Arch. Geol. PIG-PIB, Warszawa. Nr inw. $98 / 2011$.

USTAWA Z DNIA 9 czerwca 2011 r. Prawo geologiczne i górnicze. Dz.U. z 2021 poz. 1420, j.t.

Praca wpłynęła do redakcji 12.07.2021 r.

Akceptowano do druku 6.08.2021 r. 